\title{
PENGARUH PENILAIAN KINERJA DAN KOMPETENSI TERHADAP EMPLOYEE ENGAGEMENT PT. SMART SOLUTION BEKASI
}

\section{THE EFFECT OF PERFORMANCE ASSESSMENT AND COMPETENCE ON EMPLOYEE ENGAGEMENT PT. SMART SOLUTION BEKASI}

\author{
Mety Titin Herawaty ${ }^{1}$ \\ mety.mth@bsi.ac.id \\ Cepi Cahyadi ${ }^{2}$ \\ cepi.ccd@nusamandiri.ac.id ${ }^{2}$ \\ ${ }^{1}$ Fakultas Komunikasi dan Bahasa Univ. Bina Sarana Informatika Jakarta Pusat \\ ${ }^{2}$ Program Studi Sarjana, Sistem Informasi STMIK Nusa Bekasi Jakarta Pusat
}

\begin{abstract}
This study aims to determine the effect of performance and competency assessment on Employee Engagement of PT Smart Solution Bekasi employees with a population of 217 employees of PT Smart Solution Bekasi. The sampling technique in this study uses convenience samples with a total sample of 68 employees. Data collection methods used were to provide research instruments in the form of questionnaires to respondents and research methods using regression analysis with the help of SPSS 19.0. Based on a range of criteria scale tests of the answers given by respondents regarding the performance evaluation of the tendency of respondents to answer with disagreement over the statements given, it gives an illustration that the performance evaluation experienced by employees of PT Smart Solution Bekasi is relatively low. Furthermore, in the case of statements relating to competence, respondents generally agree with the statements rolled out in the questionnaire. Based on the results of the t test performance evaluation variables that affect employee engagement with $t$-count $=-0.241$. That is, this performance appraisal variable has a significant negative relationship to employee engagement. While the variable of competence has a significant effect on employee engagement, because t arithmetic = 2.210 , greater than $t$-table at significance $\alpha=0.05(t$-table $=1.671)$. Based on the results of the analysis and findings in this study, it can be concluded that the performance and competency assessment variables have a significant effect on employee engagement on employees of PT Smart Solution Bekasi.
\end{abstract}

Keywords: Performance Appraisal, Competence and Employee Engagement

\begin{abstract}
Abstrak
Penelitian ini bertujuan untuk mengetahui pengaruh dari Penilaian kinerja dan Kompetensi terhadap Employee Engagement pada karyawan PT Smart Solution Bekasi dengan Populasi karyawan PT Smart Solution Bekasi yang berjumlah 217 orang. Teknik pengambilan sampel dalam penelitian ini menggunakan convenience sample dengan jumlah sampel sebanyak 68 karyawan. Metode pengumpulan data yang digunakan adalah dengan memberikan instrument penelitian berupa kuesioner kepada responden dan Metode penelitian menggunakan analisis regresi dengan bantuan SPSS 19.0. Berdasarkan uji rentang skala kriteria terhadap jawaban yang diberikan responden mengenai penilaian kinerja kecenderungan responden menjawab dengan ketidak setujuan atas pernyataan-pernyataan yang diberikan, memberikan gambaran bahwa penilaian kinerja yang di alami karyawan PT Smart Solution Bekasi tergolong rendah. Selanjutnya pada butir pernyataan yang berkaitan dengan kompetensi, secara umum responden setuju dengan pernyataan yang digulirkan dalam kuesioner. Berdasarkan hasil uji t variabel penilaian kinerja yang berpengaruh terhadap employee engagement dengan t-hitung $=-0,241$. Artinya, variabel penilaian kinerja ini memiliki hubungan yang negative signifikan terhadap employee engagement. Sedangkan pada variabel kompetensi berpengaruh signifikan terhadap employee engagement, karena t hitung $=2,210$, lebih besar dari t-tabel pada signifikansi $\alpha=0.05$ (t-tabel $=1.671$ ). Berdasarkan hasil analisis dan temuan dalam penelitian ini,maka dapat disimpulkan variabel penilaian kinerja dan kompetensi mempunyai pengaruh yang signifikan terhadap employee engagement pada karyawan PT Smart Solution Bekasi.
\end{abstract}

Kata kunci: Penilaian Kinerja, Kompetensi dan Employee Engagement 


\section{Pendahuluan}

Peranan sumber daya manusia sangat penting keberadaannya dalam sebuah organisasi diperlukan untuk pelaksanaan dan pengembangan organisasi. Salah satu tanggung jawab besar yang harus diemban oleh bagian sumber daya manusia dalam mengelola dan mengembankan karyawan karena karyawan harus mampu melaksanakan tugas-tugas dan tanggung jawab sesuai dengan tuntutan organisasi tersebut supaya lebih dinamis. Sehingga organisasi memerlukan sumber daya manusia yang memiliki nilai yang kuat, flksibel dan dapat beradaptasi dengan perubahan lingkungan. Sumber daya manusia yang berbasis kompetensi dapat meningkatkan kapasitas dan membangun pondasi karena apabila orangorang yang bekerja dalam organisasi memiliki kompetensi yang tepat sesuai dengan tuntutan pekerjaannya, maka dia akan mampu baik dari segi pengetahuan, keterampilan maupun mental serta karakter produktifnya di bidangnya dan sebagai faktor pendorong, penilaian kinerja berdasarkan kompetensi.

Permasalahan yang dihadapi oleh PT. Smart Solution Bekasi berkaitan dengan engagement sumber daya manusia perusahaan yang dimiliki karyawan, sehingga dapat menimbulkan berbagai permasalahan dalam kualitas produk yang dihasilkan perusahaan tersebut. Permasalahan ini dapat menyebabkan timbulnya kerugian dalam perusahaan, Peran kinerja dari karyawan sangat penting karena mengingat perusahaan ini bergerak dalam bidang jasa dan produk komputer. kualitas produk yang dihasilkan juga dapat dipengaruhi oleh kemampuan sumber daya manusia. Salah satu factor yang penting untuk menghasilkan produk yang berkualitas adalah keahlian dan kemampuan dari sumber daya manusia yang dimiliki perusahaan. Beberapa upaya memang bukan tidak pernah dilakukan perusahaan untuk memperbaiki hasil etos kerja melalui penambahan jam kerja diharapkan bisa menggenjot produktivitas karyawan meskipun penambahan jam kerja bagi karyawan dianggap sebagai salah satu solusi meningkatkan etos kerja. Namun disisi lain penambahan jam kerja tidak akan efektif jika hanya menjadikan karyawan bosan di kantor. Dalam kajian penelitian yang dilakukan manajeman PT Smart Solutian beberapa waktu lalu, menyebutkan produktivitas karyawan sangat rendah.

Employee Engagement menjadi hal yang penting untuk diperhatikan oleh segenap eksekutif puncak di perusahaan PT Smart Solution Bekasi. Banyak kalangan berpendapat bahwa Employee Engagement harus menjadi perhatian serius oleh eksekutif di bidang sumber daya manusia maupun eksekutif puncak agar perusahaan supaya dapat bertahan. Pendapat ini juga diperkuat oleh beberapa studi yang mengkorelasikan antara tingginya Engagement dengan pencapaian target perusahaan, dan hasilnya sangat positif. Employee Engagement merupakan kesadaran dan energi yang terpusatkan, sebagai bukti dari rasa inisiatif pada individu, proses adaptasi, usaha dan pengarahan pada tujuan organisasi, Employee engagement muncul sebagai upaya pengembangan dari konsep-konsep sebelumnya seperti kepuasan kerja karyawan, serta perilaku organisasi karyawan dan perusahaan yang memiliki iklim kerja secara positif adalah karyawan yang terlibat secara aktif di dalam perusahaan, pengukuran Employee Engagement sebagai salah satu tolak ukur dalam menentukan kinerja karyawan telah menjadi trend yang terus berkembang di suatu organisasi dalam Nabilah Ramadhan, Jafar Sembiring (2014), Hal ini disebabkan karena dengan adanya karyawan yang memiliki Engagement yang baik dengan perusahaan tempat bekerja, maka mereka akan memiliki antusiasme yang besar untuk bekerja. bahkan 
terkadang jauh melampaui tugas pokok yang tertuang dalam kontrak kerja mereka, penelitian lain yang mengkaitkan antara Employee Engagement dengan HRM practices (praktek sumber daya manusia) baik secara langsung maupun tak langsung, Francisca Hermawan, Yuvenny Christine (2014). Penilaian Kinerja dan kompetensi. Berdasarkan telaah teoritis, hasil-hasil penelitian terdahulu, serta kerangka pemikiran teoritis tentang faktor-faktor yang berpengaruh terhadap employee engagement. (Dessler, 2004:70). Penilaian Kinerja (Performance Appraisal) adalah sistem formal untuk memeriksa atau mengkaji dan mengevaluasi kinerja seseorang atau kelompok, penilaian kinerja adalah uraian sistematis tentang kekuatan atau kelebihan dan kelemahan yang berkaitan dengan pekerjaan seseorang atau sebuah kelompok, Eman S, Puji I dan Yosi S (2012). Kompetensi adalah jenis keahlian, pengetahuan, dan kemampuan yang diperlukan untuk menunaikan sebuah pekerjaan secara efektif faktor kompetensi karyawan yang meliputi kesesuaian pengetahuan dan ketrampilan dalam pelaksanaan tugas akan memberikan dampak pada kinerja karyawan sebagai perwujudan prestasinya. Sari Ika Rinawati dan Kusni Ingsih (2012).

Tujuan penelitian memperoleh bukti empirik (apriori), re-theory pada Employee Engagement, middle theory pada kompetensi karyawan, apply theory pada penilaian kenerja, kompetensi karyawan, dan Employee Engagement sesuai dengan identifikasi masalah bagaimana pengaruh penilaian kinerja kompetensi terhadap Employee Engagement secara parsial maupun simultan pada PT Smart Solution Bekasi.

Kerangka konseptual dalam penelitian ini adalah sebagai berikut:

\section{Gambar 1. Kerangka Konseptual}

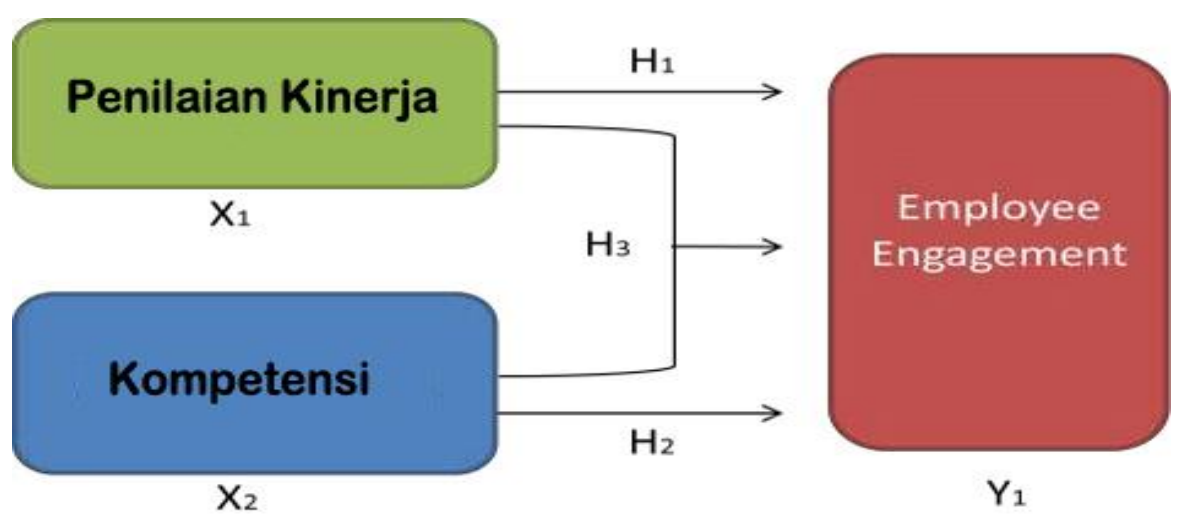

H1 : Diduga Penilaiaa kinerja berpengaruh terhadap Employee Engagement pada PT. Smart Solustion

H2 : Diduga Kompetensi berpengaruh terhadap EmployeeEengagement pada PT. Smart Solustion

H3 : Diduga Penilaiaa kinerja dan Kompetensi terhadap EmployeeEengagement pada PT. Smart Solustion 


\section{Metode}

Penelitian ini merupakan penelitian deskritif statistik analitis dengan menggunakan metode korelasional serta melalui pendekatan verifikatif karena menggunakan uji pembuktian hipotesis. Metode korelasional adalah metode yang ingin melihat secara empiris hubungan antara satu atau lebih variabel bebas terhadap satu atau lebih variabel terikat. Dalam penelitian ini variabel penilaian kinerja dan kompetensi terhadap employee engagement PT Smart Solution Bekasi. Penelitian ini digolongkan kedalam penelitian kuantitatif yang mengkuantifikasi variasi dalam suatu isu, masalah atau fenomena, informasi yang dikumpulkan berupa variabel kuantitatif dan analisis yang dilakukan bertujuan untuk memastikan tingkat variasi tersebut. Dalam perspektif sifat penelitian ini merupakan jenis desain penelitian non-eksperimental dimana variabel yang diteliti tidak dimanipulasi dan dikontrol oleh peneliti karena manifestasinya sudah berlangsung dan tidak dapat dimanipulasi. Berdasarkan periode referensi yang digunakan, penelitian ini termasuk dalam penelitian restropektif (restropective study) karena penelitian ini berusaha untuk meneliti suatu fenomena, situasi atau isu yang sudah terjadi di masa lalu atau sudah ada sebelumnya. Teknik pengambilan sampel yang digunakan pada penelitian ini adalah nonprobability sample (convenience sample). Dalam convenience sample peneliti memilih responden berdasarkan ketersediaan untuk mengakses responden (Mulyanto Heru dan Wulandari Anna, 2010). Dalam penelitian ini alat pengumpul data yang digunakan berupa kuisioner. Selain itu peneliti juga akan melakukan interview dengan beberapa orang.

Populasi pada penulisan ini adalah seluruh karyawan pada PT Smart Solution Bekasi yang berjumlah 217 orang. Kualifikasi populasi adalah karyawan, dengan level jabatan dari tingkat staf, maupun struktural, berusia antara 25 sampai dengan 55 tahun dengan Masa Kerja Efektif (MKE) >1 tahun berdasarkan unit kerjanya masing-masing. Alasan penulis memilih karyawan berdasarkan unit kerja, agar data yang disimpulkan dari penelitian nantinya dapat mewakili seluruh suara dari masing-masing unit kerja yang ada di PT Smart Solution Bekasi.

Metode pengambilan sampel probabilitas sampling, yaitu teknik pengambilan sampel terhadap elemen di dalam populasi yang diketahui mempunyai kesempatan atau probabilitas untuk terpilih. Sedangkan penarikan sampel menggunakan Systematic Sampling, yaitu penarikan sample dengan memilih elemen pada urutan tertentu, dengan mengurutkan karyawan sebanyak 217 orang yang terdiri dari berbagai kelompok jabatan, pangkat dan golongan serta tingkat pendidikan dan mengurutkan dari usia yang termuda (25 tahun) sampai dengan yang tertua (55 tahun). Setelah menentukan interval dengan cara stratified random sampling dari jumlah karyawan yang ada.

Variabel yang diteliti terdiri dari variable bebas yang meliputi penilaian kinerja, kompetensi serta variabel terikat yaitu employee engagement.

\section{Uji Validitas}

Uji validitas dilakukaan dengan mengukur korelasi antara variabel/item dengan skor total varaibel. Cara mengukur validitas konstruk yaitu dengan mencari korelasi antara masing-masing pernyataan dengan skor total menggunakan rumus Pearson Correlation Product Moment, sebagai berikut: 


$$
\begin{array}{ll}
\mathbf{r}_{\mathrm{xy}}=\frac{n \Sigma x y-(\Sigma x)(\Sigma y)}{\sqrt{\left(\left(n \Sigma x^{2}-(\Sigma x)^{2}\right)\right)\left(\left(n \Sigma y^{2}-(\Sigma y)^{2}\right)\right.}} \quad & \text { Keterangan: } \\
& \mathrm{r}_{\mathrm{xy}}=\text { Korelasi antara variabel X dan } \mathrm{Y} \\
& \mathrm{n}=\text { Jumlah responden } \\
& \mathrm{X}=\text { Skor butir instrumen } \\
& \mathrm{Y}=\text { Skor total item instrumen } \\
& \Sigma x=\text { Jumlah skor X } \\
& \Sigma y=\text { Jumlah skor Y }
\end{array}
$$

Setelah semua korelasi untuk setiap pernyataan dengan skor total diperoleh, nilai-nilai tersebut dibandingkan dengan nilai kritik. Selanjutnya, jika nilai koefisien korelasi Pearson CorrelationProduct Moment dari suatu pernyataan tersebut berada diatas nilai tabel kritik, maka pernyataan tersebut signifikan. Setelah nilai korelasi didapat, nilai tersebut dibandingkan dengan nilai $r_{\text {tabel }}$ dengan kaidah :

Jika $r_{\text {hitung }}>r_{\text {tabel }}$, maka kuesioner sebagai instrument yang digunakan adalah valid Jika $r_{\text {hitung }}<r_{\text {tabel }}$, maka kuesioner sebagai instrument yang digunakan adalah tidak valid Analisis Regresi

Analisis regresi linear berganda adalah hubungan secara linear antara dua atau lebih variabel independen $\left(\mathrm{x} 1, \mathrm{x} 2, \ldots . . \mathrm{x}_{\mathrm{n}}\right)$ dengan variabel dependen $(\mathrm{Y})$. analisis ini untuk mengetahui arah hubungan antara variable independen dengan variabel dependen apakah masing-masing variable independen berhubungan positif atau negatif dan untuk memprediksi nilai dari variabel dependen apabila nilai variabel independen mengalami kenaikan atau penurunan.

Rumus persamaan regresi linear adalah sebagai berikut:

$$
\mathbf{Y}=\mathbf{a}+\mathbf{b}_{1} \mathbf{X}_{1}+\mathbf{b}_{2} \mathbf{X}_{2}+\ldots . . \mathbf{b}_{\mathbf{n}} \mathbf{X}_{\mathbf{n}}
$$

Keterangan :

$$
\begin{array}{lll}
\mathrm{Y} & = & \text { Variabel dependen (nilai yang diprediksikan) } \\
\mathrm{X} 1 & \text { dan } & = \\
\mathrm{Xn} & & \text { Kariabel independen } \\
\mathrm{A} & & \begin{array}{l}
\text { Konstanta (nilai Y apabila } \mathrm{X} 1, \mathrm{X} 2 \ldots . . \mathrm{X}=0) \\
\text { penurunan })
\end{array}
\end{array}
$$

\section{Uji Hipotesis}

\section{Uji t-statistik}

Uji ini dilakukan untuk membuktikan bahwa Penilaian Kinerja, dan kompetensi mempengaruhi Employee Engagement digunakan uji t statistic, Dasar keputusannya adalah sebagai berikut:

\section{KoefisienDeterminasi (R2)}

$$
\begin{aligned}
& \text { Ho : diterima bila t hitung }<\mathrm{t} \text { tabel } \\
& \mathrm{Ha} \text { : diterima bila } \mathrm{t} \text { hitung }>\mathrm{t} \text { table }
\end{aligned}
$$

Koefisien determinasi dilambangkan dengan R2 merupakan proporsi hubungan antara Y dengan X. Nilai koefisien determinasi adalah diantara 0 (nol) dan 1 (satu). Koefisien ini menunjukkan seberapa besar kontribusi variabel independent terhadap variabel dependen. 


\section{Pembahasan}

\section{Analisis Reabilitas}

Reabilitas merupakan ukuran suatu kestabilan dan konsistensi responden dalam menjawab hal yang berkaitan dengan pertanyaan yang merupakan dimensi suatu variabel dan disusun dalam suatu bentuk kuesioner. Uji Reabilitas digunakan untuk mengukur/menunjukkan konsistensi alat ukur dalam mengukur gejala yang sama. Pada variabel yang diteliti dapat dilihat nilai alpha cronbach's. Sedangkan untuk Uji Reabilitas berdasarkan hasil perhitungan dengan menggunakan software SPSS 19 dikatakan reabel jika hasil uji reabilitas sebagai berikut;

\section{Cronbach alpha <0,6 : reabilitas buruk \\ Cronbach alpha 0,6-0,79: reabilitas diterima \\ Cronbach alpha _ 0,8 : reabilitas baik \\ Variabel Penilaian Kinerja (X1) \\ Reliability Statistics}

\begin{tabular}{|c|c|}
\hline Cronbach's Alpha & $\mathrm{N}$ of Items \\
\hline .716 & 10 \\
\hline \multicolumn{2}{|c|}{$\begin{array}{c}\text { Variabel Kompetensi }\left(\mathbf{X}_{2}\right) \\
\text { Reliability Statistics } \\
\end{array}$} \\
\hline Cronbach's Alpha & $\mathrm{N}$ of Items \\
\hline .723 & 10 \\
\hline \multicolumn{2}{|c|}{ Variabel Employee Engagement (Y) } \\
\hline \multicolumn{2}{|c|}{ Reliability Statistics } \\
\hline Cronbach's Alpha & $\mathrm{N}$ of Items \\
\hline .72 & 11 \\
\hline
\end{tabular}

Hasil Pengujian Reliabilitas untuk masing-masing variabel yang diringkas pada tabel 1 berikut ini:

Tabel 1. Hasil Pengujian Reabilitas

\begin{tabular}{|l|c|c|}
\hline \multicolumn{1}{|c|}{ Variabel } & Cronbach'sAlpha & Keterangan \\
\hline Penilaian Kinerja & 0,716 & Reliabel \\
\hline Kompensasi & 0,723 & Reliabel \\
\hline Employee Engagement & 0,729 & Reliabel \\
\hline
\end{tabular}

Sumber : Data diolah SPSS 2019

Hasil uji reliabilitas tersebut menunjukkan bahwa semua variabel mempunyai koefisien Alpha yang cukup besar yaitu diatas 0,60 sehingga dapat dikatakan semua konsep pengukur masing-masing variabel dari kuesioner adalah reliabel sehingga untuk selanjutnya item-item pada masing-masing konsep variabel tersebut layak digunakan sebagai alat ukur.

\section{Anilisis Regresi Linear Berganda}

Regresi antara variabel Penilaian Kinerja dan Kompetensi terhadap Employee Engagement dapat digambarkan dalam pengolahan data dengan software SPSS versi 19.00 Nilai R2 (koefisien determinasi) sebesar 0,758. Hal ini menunjukkan bahwa besarnya 
variasi yang memberikan pengaruh bersama-sama antara Penilaian Kinerja dan Kompetensi terhadap Employee Engagement sebesar 75,8\% atau sisanya 24,2\% dipengaruhi oleh faktorfaktor lain yang tidak diteliti.

Tabel 2. Hasil Estimasi Regresi Linear Berganda Coefficients ${ }^{\mathbf{a}}$

\begin{tabular}{|c|c|c|c|c|c|}
\hline \multirow[b]{2}{*}{ Model } & \multicolumn{2}{|c|}{ Unstandardized Coefficients } & \multirow{2}{*}{\begin{tabular}{|c|} 
Standardized Coefficients \\
Beta
\end{tabular}} & & \multirow[b]{2}{*}{ Sig. } \\
\hline & B & Std. Error & & & \\
\hline 1 (Constant) & 15.613 & 4.248 & & 3.676 & .000 \\
\hline Penilaian Kinerja & -.065 & .271 & -.05 & -.241 & .810 \\
\hline Kompetensi & .599 & .271 & .50 & 2.210 & .031 \\
\hline
\end{tabular}

a. Dependent Variable: Employee Engagement

Sumber : Data diolah SPSS 2019

Variabel Penilaian Kinerja terhadap Variabel Employee Engagement :

Ho = tidak ada pengaruh Penilaian Kinerja terhadap Empolyee Engagement

$\mathrm{Ha}=$ ada pengaruh Penilaian Kinerja terhadap Empolyee Engagement

Dari perhitungan didapatkan nilai signifikansinya untuk variabel Penilaian Kinerja adalah $0,810<0,05$ maka Ho diterima atau Ha ditolak. Dengan demikian ditarik kesimpulan variabel Penilaian Kinerja tidak memiliki pengaruh yang signifikan terhadap variabel Empolyee Engagement.

Variabel Kompetensi terhadap Variabel Empolyee Engagement.

Ho = tidak ada pengaruh Kompetensi terhadap Empolyee Engagement .

$\mathrm{Ha}=$ ada pengaruh Kompetensi terhadap Empolyee Engagement .

Dari perhitungan didapatkan nilai signifikansinya untuk variabel Kompetensi adalah $0,031<0,05$ maka Ho ditolak atau Ha diterima. Dengan demikian ditarik kesimpulan variabel Kompetensi memiliki pengaruh yang signifikan terhadap variabel Empolyee Engagement. Diperoleh nilai koef

isien regresi pada variabel penilaian kinerja adalah sebesar -0,065. Ini berarti bahwa dengan faktor lain dianggap konstan, pengaruh penilaian kinerja lebih kecil dibandingkan dengan kompetensi karena hasilnya adalah sebesar -0,065. Nilai koefisien regresi pada variabel Kompetensi adalah sebesar 0,599. Ini berarti bahwa dengan faktor lain dianggap konstan, maka setiap peningkatan Kompetensi maka kinerja akan ikut meningkat sebesar 0,599. Beta untuk X1=-0,055. dan untuk X2 =0,509. Dengan demikian variabel yang paling dominan, yang mempunyai koefisien beta $=0,509$ adalah Kompetensi.

Maka dengan mengacup ada hasil beta (Unstandartdized Coefficients) di atas dapat dihasilkan persamaan regresi sebagai berikut:

$$
Y=15.613-0.065 X 1+0.559 X 2
$$

\section{Regresi Linear Berganda $X_{1}$ dan $X_{2}$ terhadap $Y$}

Tabel 3. Anova Regresi Linear Berganda $X_{1}$ dan $X_{2}$ terhadap $Y$. ANOVA ${ }^{b}$

\begin{tabular}{|ll|r|r|r|r|r|}
\hline \multicolumn{1}{|l|}{ Model } & Sum of Squares & df & Mean Square & F & Sig. \\
\hline 1 & Regression & 327.135 & 2 & 163.567 & 8.760 & $.000^{\mathrm{a}}$ \\
& Residual & 1213.630 & 65 & 18.671 & & \\
& Total & 1540.765 & 67 & & & \\
\hline
\end{tabular}


Tabel 3. Anova Regresi Linear Berganda $X_{1}$ dan $X_{2}$ terhadap Y. ANOVA ${ }^{b}$

\begin{tabular}{|ll|r|r|r|r|r|}
\hline \multicolumn{1}{|l|}{ Model } & Sum of Squares & df & Mean Square & F & Sig. \\
\hline 1 & Regression & 327.135 & 2 & 163.567 & 8.760 & $.000^{\mathrm{a}}$ \\
& Residual & 1213.630 & 65 & 18.671 & & \\
& Total & 1540.765 & 67 & & & \\
\hline
\end{tabular}

a. Predictors: (Constant), Kompetensi, Penilaian Kinerja

b. Dependent Variable: Employee Engagement

Sumber : Data diolah SPSS 2019

Uji simultan dengan F-test bertujuan untuk mengetahui pengaruh bersama sama variabel independen terhadap variabel dependen. dari Uji ANOVA atau F-test, didapat F hitung adalah 8.760 dan dengan probabilitas 0,000 . Probabilitas jauh lebih kecil $(<)$ dari 0,05 maka model regresi dapat digunakan untuk memprediksi Employee Engagement. Pada output SPSS tersebut juga menunjukkan p-value $0,000<0,05$ yang artinya adalah signifikan dalam hal ini, Ho ditolak atau Ha diterima. Dengan demikian dapat disimpulkan bahwa variabel Penilaian Kinerja dan Kompetensi secara bersama sama berpengaruh terhadap Employee Engagement.

\section{Analisis Parsial}

Kemudian untuk mengetahui atau menguji pengaruh masing-masing faktor penilaian kinerja dan kompetensi terhadap employee engagement, maka dapat dijelaskan secara lebih rinci dari faktor-faktor tersebut, yang dapat dilihat pada 4

Tabel 4. Uji Parsial Coefficients ${ }^{a}$

\begin{tabular}{|l|l|l|l|l|l|}
\hline \multirow{2}{*}{ Model } & \multicolumn{2}{|l|}{ Unstandardized Coefficients } & Standardized Coefficients & & \\
\cline { 2 - 4 } & $\mathrm{B}$ & Std. Error & Beta & $\mathrm{t}$ & Sig. \\
\hline 1 (Constant) & 15.613 & 4.248 & & 3.676 & .000 \\
Penilaian Kinerja & -.065 & .271 & -.055 & -.241 & .810 \\
Kompetensi & .599 & .271 & .509 & 2.210 & .031 \\
\hline
\end{tabular}

a. Dependent Variable: Employee Engagement

Sumber : Data diolah SPSS 2019

Berdasarkan hasil pengujian parsial mengenai pengaruh masing-masing variabelpenilaian kinerja dan kompetensi terhadap employee engagement di PT Smart Solution Bekasi, maka dapat diuraikan sebagai berikut :

- Faktor Penilaian Kinerja $\left(\mathrm{X}_{1}\right)$

Faktor penilaian kinerja tidak berpengaruh signifikan terhadap employee engagement dengan uji statistik melalui uji t dengan taraf nyata 5\%, di mana memiliki nilai thitung ($0,241)<t_{\text {tabel }}(1,671)$ dan memiliki nilai probabilitas $0,810>0,05$.

- Faktor Kompetensi $\left(\mathrm{X}_{2}\right)$

Faktor kompetensi berpengaruh signifikan terhadap employee engagement dengan uji statistik melalui uji $t$ dengan taraf nyata $5 \%$, di mana memiliki nilai $t_{\text {hitung }}(2,210)>t_{\text {tabel }}$ $(1,671)$ dan memiliki nilai probabilitas $0,031<0,05$.

Faktor yang paling dominan berpengaruh pada employee engagement di PT Smart Solution Bekasi, adalah kompetensi karena memiliki nilai thitung terbesar dan memiliki nilai 
probabilitas terkecil, dimana semakin kecil nilai probabilitas, akan semakin besar pengaruhnya terhadap peningkatan employee engagement di PT Smart Solution Bekasi

\section{Analisis Penilaian Kinerja terhadap Employee Engagement}

Mengenai jawaban responden variabel penilaian kinerja pada karyawan PT Smart Solution Bekasi, dengan menunjukan persepsi yang baik terlihat dari nilai rata-rata keseluruhan skor. Skor rata-rata tertinggi dari hasil penelitian adalah dimensi kesesuaian dengan strategi perusahaan. Saat ini penilaian kinerja belum secara jelas menyelaraskannya dengan visi, misi dan rencana jangka panjang PT Smart Solution Bekasi. Namun visi dan misi serta rencana jangka panjang senantiasa di sosialisasikan kepada karyawan melalui proses coaching councelling, serta momen diskusi antara atasan dan bawahan saat melakukan penilaian kinerja. Sehingga tercipta suatu kesinambungan yang saling mendukung tercapainya tujuan PT Smart Solution Bekasi. Penilaian kinerja seharusnya memiliki proses review, planning, coaching dan councelling.

Berdasarkan penilaian kinerja tersebut karyawan akan mendapatkan feedback atau umpan balik yang berguna untuk mendukung karir seorang karyawan. Seluruh hal tersebut yang menjadi poin kebih bagi penilaian karyawan, penilaian kinerja juga signifikan mempengaruhi employee engagement. Semakin baik praktik penilaian kinerja karyawan, maka semakin tinggi persepsi karyawan terhadap rasa employee engagement. PT Smart Solution Bekasi kedepannya memerlukan metode penilaian kinerja yang sesuai dengan perkembangan kebutuhan perusahaan. penilaian kinerja berbasis kompetensi yang selaras dengan visi misi dan rencana jangka panjang perusahaan yang bisa terlihat dari kutipan komentar responden. walaupun secara keseluruhan penilaian kinerja sudah cukup baik namun mereka menginginkan adanya perbaikan dalam sistem penilaian kinerja karyawan agar lebih adil, yang secara langsung akan berdampak pada pengahargaan perusahaan terhadap kontribusi masing-masing karyawan sehingga perlu terus ditingkatkan agar perusahaan dapat memupuk dan meningkatkan employee engagement di kalangan karyawannya.

\section{Analisis Kompetensi terhadap Employee Engagement}

Alasan kualitatif dengan besarnya nilai korelasi yang tercipta antara variabel kompetensi dengan employee engagement lebih, karena sebagaian besar karyawan di PT Smart Solution Bekasi memiliki kompetensi yang relatif baik. yang tinggi berarti merata pada karyawan dari tingkat bawah sampai atas. Ada kompetensi yang tinggi akan mendukung employee engagement, sehingga karyawan akan melakukan pekerjaan secara sungguh-sungguh karena keterikatannya pada instansi yang ada. Kondisi tersebut juga berarti bahwa kondisi kompetensi dan mendukung employee engagement dan hal ini berarti mendukung teori-teori kompetensi yang selama ini dipelajari. Jika dilihat lebih mendalam nilai hubungan yang tercipta antara variabel kompetensi dengan employee engagement jelas menunjukkan ke arah positif dan memiliki korelasi yang tinggi. Besarnya hubungan tersebut lebih disebabkan karena adanya sikap patuh dan segan dari para karyawan untuk patuh dan loyal kepada instansi. Selain itu karyawan juga merasa Karakter pribadi, Pengetahuan, Konsep diri, keterampilan, dan motivasi yang ada saat ini masih mampu memberikan pengaruh yang kuat dan positif bagai para karyawan.

Selain itu pula jika dilihat bahwa hasil nilai $r$ korelasi yang dihasilkan pada variabel kompetensi memiliki nilai besar. Hal tersebut juga disebabkan karena para mayoritas 
karyawan merupakan karyawan yang masih relatif memiliki pengalaman cukup lama. Dengan demikian masing-masing karyawan tersebut telah memiliki jiwa dan rasa bangga dengan organisasi beserta atribut yang dimilikinya. Namun demikian masih tetap diperlukan upaya yang lebih keras lagi dari para pimpinan atau atasan untuk lebih dapat memenuhi aspirasi dari para karyawan sehingga wujud persepsi yang baik tentang komitmen organisasi yang ideal yang mendukung kinerja karyawan dan tercipta karyawan yang ideal seperti yang diharapkan dapat terealisasi. Disadari bahwa hingga saat ini kompetensi karyawan sudah dinilai relatif baik namun demikian masih perlu dilakukan peningkatan.

\section{Analisis Penilaian Kinerja dan Kompetensi Terhadap Employee Engagement}

Sedangkan alasan kualitatif yang perlu dikemukakan dengan positif dan sangat signifikannya serta besarnya hubungan antara penilaian kinerja dan kompetensi secara besama-sama dengan variabel employee engagement adalah lebih disebabkan karena baik penilaian kinerja dan kompetensi yang terdapat di PT Smart Solution Bekasi relative baik dan memberikan dukungan kepada employee engagement. Dimensi Say memiliki skor tertinggi dibandingkan variabel lainnya. Prediktor utama Say adalah saya merekomendasikan di Dinas PT Smart Solution Bekasi sebagai tempat bekerja yang „menjanjikan . Hal ini dapat dikatakan bahwa, karyawan PT Smart Solution Bekasi merasakan suatu kebanggan dan keterikatannya, sehingga merasa perlu untuk mereomendasikannya sebagai tempat yang menjanjikan untuk bekerja. Ratarata usia karyawan yang engage berada pada usia 31 - 44 tahun.

Skor rata-rata tertinggi kedua adalah Stay. Skor tertinggi untuk dimensi Stay disebabkan oleh tingginya skor indikator untuk pernyataan saya berniat untuk menghabiskan usia produktif saya di PT Smart Solution Bekasi. Hal ini menunjukkan loyalitas yang tinggi dari karyawan. Dengan senantiasa meningkatkan Penilaian Kinerja dan Kompetensi karyawan misalnya dengan membuat beban kerja yang sesuai dengan tugas dan fungsi karyawan tersebut, menciptakan lingkungan kerja yang nyaman, adanya kebanggan terhadap instansi yang dimiliki, maka hal tersebut akan dapat meningkatkan kinerja karyawan. Penilaian Kinerja dan Kompetensi yang dimiliki karyawan sangat berkaitan erat dengan kesehatan fisik dan mental dari karyawan itu sendiri. Untuk itulah mengapa karyawan yang merasa terpuaskan dalam bekerja akan lebih sehat secara fisik dan mental dibandingkan dengan karyawan yang belum terpuaskan dalam bekerja.

Jika dilihat dari uji korelasi ganda maka dapat dilihat bahwa hubungan yang ditimbulkan dari Penilaian Kinerja dan Kompetensi secara besama-sama dengan variabel employee engagement merupakan hubungan yang cukup besar jika dilihat korelasinya. Hal tersebut jelas menunjukkan betapa penting arti pengelolaan penilaian kinerja dan kompetensi karyawan. penilaian kinerja dan kompetensi karyawan harus terus ditingkatkan agar tercipta karyawan yang memiliki employee engagement yang baik.

\section{Kesimpulan}

Berdasarkan analisis yang telah dilakukan dapat ditarik beberapa kesimpulan yaitu pada variabel penilaian kinerja yang berpengaruh terhadap employee engagement dengan thitung $=-0,241$. Artinya variabel penilaian kinerja ini memiliki hubungan yang negative signifikan terhadap employee engagement, dan pada variabel kompetensi berpengaruh 
signifikan terhadap employee engagement, karena thitung $=2,210$, lebih besar dari $t$-tabel pada signifikansi $\alpha=0.05(\mathrm{t}$-tabel $=1.671)$. dari hasil pengujian kedua variabel penilaian kinerja dan kompetensi, maka variabel yang kurang berpengaruh adalah penilaian kinerja dibandingkan kompetensi terhadap employee engagement di PT Smart Solution Bekasi. karena kompetensi yang sudah cukup baik mampu memberikan kepastian kepada karyawan tentang dampak berkompetensi tersebut pada pengembangan karirnya sebagai karyawan.

\section{Daftar Pustaka}

Dharma Surya, (2013). Manajeman Kinerja Falsafah Teori dan Penerapannya, Edisi IV, Pustaka Pelajar, Jogjakarta

Dessler, Gary (2006). Manajemen Sumber Daya Manusia, Edisi 10, terjemahan, Indeks

Dessler, Gary (2005). Human Resources Management. New Jersey : Pearson Education. Desai, Malavika,

Francisca Hermawan, Yuvenny Christine, (2014) Analisa Pengaruh Kompensasi Terhadap Kinerja Karyawan, Fakultas Ekonomi Universitas Katolik Indonesia Atma Jaya Volume 18, Nomor 2, Agustus 2014.

Hewitt (2015), Say, Stay or Strive? Unleash the Engagement Outcome You Need, Oehler, K. Adair. C,Washington DC.

Mulyanto Heru dan Wulandari Anna, Penelitian : Metode \& Analisis, Cv Agung Semarang 2010

Moekijat (2010). Manajeman Sumber Daya Manusia. Edisi 10, Bandung: Mandar Maju.

Mardia H, Yoanita Y, Sugih A, 2014 Peningkatan Employee Engagement untuk Teknisi dan Karyawan Non Administrasi Itenas, Institut Teknologi Nasional Bandung, No.01,Vol. 02.

Nabilah Ramadhan, Jafar Sembiring, 2014 Pengaruh Employee Engagement Terhadap Kinerja Karyawan di Human Capital Center PT. Telekomunikasi Indonesia, TBK. Vol.14 No. 1. April.

Sari Ika Rinawati dan Kusni Ingsih, (2012) Pengaruh Lingkungan Kerja Dan Kompetensi Terhadap Kinerja Karywan Dengan Motivasi Sebagai Varaiabel Intervening Pada Satuan Kerja Non Vertikal Tertentu (SNVT) Kementrian Pekerjaan Umum di Semarang, Jurusan Manajemen Fakultas Ekonomi dan Bisnis Universitas Dian Nuswantoro. 